The Anaesthesia Advisory Committee to the Chief Coroner of Ontario*

\section{Intraoperative death during Caesarian section in a patient with sickle-cell trait}

normal except for an increased incidence of haematuria, ${ }^{2}$ possibly because of microinfarcts in the renal papillae. ${ }^{3}$

In keeping with this view of SCT, a review of anaesthetic management concluded: "Patients with sickle cell trait are at no greater risk during angesthesia and surgery than patients with normal haemoglobin." ${ }^{* 4}$ However, further correspondence emphasized that there is "an unwarranted assumption in the summary that the anaesthetist can always guarantee adequate oxygenation. ${ }^{25}$ Although SCT is not uncommon (eight per cent of blacks ${ }^{6}$ and more rarely in East Indians and individuals of eastern Mediterranean origin) there are few reports of intraoperative and postoperative deaths in patients with $\mathrm{SCT}^{7}$ and at least one of these ${ }^{y}$ was subsequently found to have sickle cell - $\mathrm{HbC}$ discasc $^{9}$ (a combination of sickle cell trait with $\mathrm{HbC}$ which is a much more serious condition). Many others were found to be unrelated to the anaesthetic ${ }^{4}$

Therefore we wish to present a case of intraoperative death during Caesarian section under general anaesthetic which was the subject of a recent coroner's inquest. We believe the death was secondary to severe aortocaval compression in a patient with SCT

\section{Case report}

A previously healthy 28 -year-old pregnant black woman was admitted close to term in early labour with ruptured membranes. She had had four uneventful general anaesthetics in the past including one for a Caesarian section for cephalopelvic dysproportion three years before. At that time, she had received thiopentone, succinylcholine, pancuronium, Innovar, fentanyl and $\mathrm{N}_{2} \mathrm{O}$ during the anaesthetic. On the current admission, her cervix was long and uneffaced so an emergency repeat Caesarian section was planned. The patient was known to have sickle cell trait but this information was not noted by the operating room staff.

Two hours after admission the patient was taken to the operating room, where she was examined by the anaesthetist. The following data were recorded: height $163 \mathrm{~cm}$, weight $74 \mathrm{~kg}$, haemoglobin $129 \mathrm{~g} \cdot \mathrm{L}^{-1}$, pulse $88 / \mathrm{min}$., blood pressure $110 / 70 \mathrm{mmHg}$, temperature $36.7^{\circ} \mathrm{C}$, fetal heart rate 140-145/min. Chest examination was normal. 
There was no peripheral oedema. The patient had eaten last five hours preoperatively. She requested general anaesthesia.

A Boyle anaesthesia machine with a $30-70$ per cent proportioner mixing valve was used, along with a Medishield floating bellows ventilator incorporating an automatic disconnect alarm. Monitoring included electrocardiogram, temperature and pulse monitors, and a blood pressure cuff. Testimony given at the Inquest by everyone present at the operation was in general agreement on the course of events.

The patient was tilted slightly to the left with one folded OR sheet under her right hip, and given $1 \mathrm{ml}$ of Innovar IV. After five minutes of breathing 100 per cent $\mathrm{O}_{2}$ she was induced with fentanyl $50 \mu \mathrm{g}$, thiopentone $225 \mathrm{mg}$ and succinylcholine $50 \mathrm{mg}$, with the use of cricoid pressure during the induction sequence. She was intubated easily with a $8 \mathrm{~mm}$ cuffed ETT and both sides of the chest were auscultated. Normal breath sounds were heard. She was then given $4 \mathrm{mg}$ of pancuronium and ventilated with 60 per cent $\mathrm{N}_{2} \mathrm{O}: 40$ per cent $\mathrm{O}_{2}$ (minute volume $8 \mathrm{~L}$ ). Blood pressure was taken six times prior to delivery and varied between 130 and 110 systolic. The pulse rose from 90 to $110 \mathrm{bpm}$ prior to delivery. Three minutes before the delivery the patient was placed on 100 per cent $\mathrm{O}_{2}$ and given naloxone $0.2 \mathrm{mg}$ IV. Delivery occurted 23 minutes after the start of preoxygenation and 33 minutes after the patient was placed on the operating room table. Skin incision to delivery time was nine minutes. Immediately following delivery, 60 per cent $\mathrm{N}_{2} \mathrm{O}$ was reintroduced and the patient was given $250 \mu \mathrm{g}$ of fentanyl and five units of syntocinon IV.

Although the skin and abdominal wall incision was unremarkable, the surgeon noted the uterus was dark when he opened the abdomen and dark blood escaped from the uterus when it was incised. When informed of this, the anaesthetist rechecked the patient's blood pressure and pulse. These were unchanged. He checked her buccal mucus membranes and they were pink. The baby was born asphyxiated (Apgar score 2 at one minute) and the anaesthetist took the baby to resuscitate it.

With immediate intubation and ventilation with 100 per cent $\mathrm{O}_{2}$ and $\mathrm{IV}$ naloxone $(0.04 \mathrm{mg})$ the baby was pink and vigorous in one to two minutes (Apgar score ten at six minutes). While the anaesthetist was resuscitating the baby, he noted the maternal pulse rate dropping by listening to the ECG audio output and asked the circulating nurse to check the patient's blood pressure. It was unobtainable. The anaesthetist was able to extubate the baby and return to the mother immediately. The surgeon reported the aortic pulse was weak and slow. The patient was ventilated manually with 100 per cent $\mathrm{O}_{2}$ and chest movement was checked. Despite atropine $1.2 \mathrm{mg}$, and two $20 \mathrm{mg}$ doses of ephedrine IV, the aortic pulse became impalpable and CPR was begun. During resuscitation, the cardiac arrest team and a second anaesthetist arrived to assist. Despite multiple doses of epinephrine and sodium bicarbonate, a fluid bolus, $\mathrm{CaCl}_{2}$, and an isoproterenol drip, the paticnt progressed from the original sinus bradycardia with electromechanical dissociation to an agonal rhythm to asystole and was pronounced dead.

A chest $x$-ray done on the operating table showed the endotracheal tube in correct position. Blood gases drawn ten minutes after $\mathrm{CPR}$ started showed $\mathrm{pH} 7.13, \mathrm{pCO}_{2}$ $74 \mathrm{mmHg}(10 \mathrm{kPa})$ and $\mathrm{pO}_{2} 16.3 \mathrm{mmHg}(2.2 \mathrm{kPa}) . \mathrm{Blood}$ was taken from the femoral area and could have been venous. Autopsy findings revealed only congestion of the viscera (lungs, liver, spleen, kidneys, and pancreas) with widespread sickling. Haemoglobin electrophoresis revealed 56 per cent $\mathrm{HbA}$ and 40 per cent $\mathrm{HbS}$. There was no coronary or valvular heart disease, no cardiomyopathy, no emboli (of air, amniotic fluid or thrombus), no cardiac tamponade and no hidden blood loss. The stomach contained partially digested food. There were no particles or other signs of aspiration in the airways. The anaesthetic machine was checked immediately following the incident by a second anaesthetist and a respiratory technologist. It delivered appropriate $\mathrm{O}_{2}$ concentrations. It was impounded and checked twice later on (by the manufacturer and by the Medical Devices Branch of Health and Welfare, Canada) and no defects which would significantly affect its function were discovered.

\section{Discussion}

The circumstances of this death, as established during the Inquest, rule out most of the common causes of intraoperative hypoxia or shock (e.g., hypoxic gas mixtures, aspiration of gastric contents, circuit disconnection, hypoventilation, misplaced endotracheal tube, cardiomyopathy, myocardial infarction, cardiac tamponade, sepsis, bleeding or embolus). This leaves only a few uncommon possibilities. Anaphylaxis to any of the anaesthetic drugs is unlikely because they were given almost twenty minutes prior to the haemodynamic deterioration. Sympathetic overactivity and arrest following naloxone is equally unlikely because the deterioration only occurred after injection of more fentanyl and reinstitution of nitrous oxide. Also, the patient never had severe tachycardia or ventricular ectopics which would be expected in this setting. Certainly the anaesthetic technique used was unusual. It does not follow the recommended pattern of 50 per cent $\mathrm{N}_{2} \mathrm{O}: \mathrm{O}_{2}$ plus a low dose of an inhalation agent prior to delivery. The technique used could lead to maternal awareness, but does not account for the findings in this case.

This leaves as the only possibility that there had been a 
severe form of concealed aortocaval compression ${ }^{10}$ while the patient was in the supine position (she was not tilted very much - probably less than $3 \mathrm{~cm}$ with the folded $\mathrm{OR}$ sheet). This would explain the congested, cyanotic uterus prior to delivery while the upper body circulation was still stable and the mucus membranes pink.

Following delivery, a large proportion of the patient's total blood volume, which may have been stagnant for more than 30 minutes, would be released suddenly. This blood would be acidotic, with a high potassium concentration and could contain a significant proportion of sickled cells.

When this bolus reached the heart it could cause cardiac depression and bradycardia and a vicious cycle of further hypoxia and stasis would be started. Once this was well under way, the presence of the sickle cell trait would make resuscitation difficult or impossible. The anaesthetic chart for the first Caesarian section did not mention tilting but evidence given at the Inquest was that tilting was a routine practice at that time. However, differences in the size and shape of the uterus in the two pregnancies could have led to differences in aortocaval compression.

Recent literature on the sickle cell trait has emphasized the fact that complications may be very rare but they do occur. Diggs, in his extensive review ${ }^{7}$ discusses several arcas of concern. Paticnts with SCT have had splenic infarcts when exposed to altitude (greater than $3000 \mathrm{~m}$ ) and in vivo sickling has been discovered in people with SCT at this altitude. The incidence of sudden death during exercise is higher in young men with SCT. In one study of military training, all four sudden deaths occurred in individuals with SCT. " Therefore, because of these risks Diggs $^{12}$ concludes that military personnel with sickle cell trait should be excluded from training and assignment as aircrew or divers, and should be excluded from special operations that require maximum stamina and exertion.

Similarly, anaesthetists should recognize that while problems with patients with sickle cell trait may be rare, they are not non-existent. If patients with SCT become severely hypoxic, acidotic or shocked from any cause, they may be difficult to resuscitate. Therefore every effort should be made to determine the sickle cell status of patients in the high risk groups preoperatively, by history and routine sickle cell testing.

All patients with SCT undergoing general anaesthesia should be monitored to assure constant adequate tissue oxygenation. The pulse oximeter or transcutaneous $\mathrm{pO}_{2}$ monitors represent convenient non-invasive methods. Special precautions must be taken to avoid local ischaemia, stagnation or cooling. No tourniquets should be used. Special precautions, including exchange transfusion, may be necessary for open heart surgery. Placing the pulse oximeter probe on the patient's toe during Caesarian section should monitor the adequacy of the patient's tilt to the left. The pulse oximeter would detect any significant hidden aortocaval compression and thus prevent local stagnation and hypoxia below the level of the uterus.

An important reminder from this case is that a second physician trained in infant resuscitation should be present at all Caesarian sections. This allows the anaesthetist to concentrate solely on the mother and to avoid any need to deal with two critically ill patients simultancously.

\section{Acknowledgement}

The authors would like to thank Nancy Davies for preparing the manuscript and Dr. R.G. Huntsman for sharing both his expertise and his references.

\section{References}

1 May A, Huehns ER. The mechanism and prevention of sickling. Br Med Bull 1976; 32: 223-33.

2 Heller P, Best WR, Nelson RB, Becktel J. Clinical implications of sickle-cell trait and glucose-6-phosphate dehydrogenase deficiency in hospitalized black malc paticnts. $\mathrm{N}$ Engl J Med 1979; 300: 1001-5.

3 Mostofi FK, Vorder Bruegge CF, Diggs LW. Lesions in kidneys removed for unilateral hematuria in sickle cell disease. Arch Pathol 1957; 63: 336-51.

4 Searle JF. Anacschesia in sickle cell states: a review. Anaesthesia 1973; 28: 48-58.

5 Howells TH, Huntsman RG. Anaesthesia in sickle cell states (letter). Anaesthesia 1973; 28; 339-41.

6 Molulsky AG. Frequency of sickling disorders in U.S. blacks. N Engl J Med 1973; 288: 31

7 Diggs $L W$, The sickle cell trait in relation to the training and assignment of duties in the Armed Forces. III. Hyposthenuria, hematuria, sudden death, rhabdomyolysis and acute tubular necrosis. Aviat Space Environ Med 1984; 55 : 358-64.

8 Konotey-Ahulu FID. Anaesthetic deaths and the sickle cell trait (letter). Lancet 1969; 1: 267-8.

9 Black AJ, Condon PI, Gompels BM, Green RL, Huntsman $R G$, Jenkins $G C$. Sickle cell haemoglobin $C$ disease in London. J Clin Path 1972; 25: 49-55.

10 Bieniarz J, Crottogini JJ, Curuchet E et al. Aortocaval compression by the uterus in late human pregnancy. $\mathrm{Am} J$ Obster Gynecol 1968; 100: 203.

11 Jones SK, Binder RA, Donowho EM. Sudden death in sickle cell trait. N Engl J Med 1970; 283; 323-5.

$12 \mathrm{Diggs} L W$. The sicklc cell trait in relation to the training and assignment of duties in the Armed Forces: IV Considerations and recommendations. Aviat Space Environ Med 1984; 55: 487-92. 


\section{Résumé}

On rapporte l'histoire d'une femme porteuse d'une drépanocytose latente ayan subi une césarienne sous anesthésie générale au cours de laquelle elle a présenté un arrêt cardiaque suivi d'un décès. Parce que les causes communes d'hypoxie intraopératoire et létat de choc ont été éliminés dans ce cas, on pense que le décès était dâ à une compression sévère et non détectée de l'aorte ainsi que de la veine cave.

Après la délivrance, la libération d'un grand volume de sang hypoxémique, acidotique avec des cellules falsiformes a pu provoquer une dépression myocardique et un arrêt. Le fait que les membranes muqueuses de la patiente étaien rosacécs ot qu'elle présentait un état hémodynamique stable alors que son utêrus était cyanotique avant la delivrance, fournissait une preave positive de caut hypothèse.

On suggère que même si les complications secondaires à la drépanocyrose lars de l'anesthésie générale sont très rares, elles peuvent cependant survenir. On discute des méthodes de surveillance dans tels cas. 